\title{
Development of Dribling Training Models on Athletes Padang State University Basketball
}

\author{
Hendri Neldi \\ Faculty of Sports Sciences, Universitas Negeri Padang Padang, Indonesia \\ *Corresponding author. Email: hendrineldi62@gmail.com
}

\begin{abstract}
The UNP Basketball Club is one of the clubs that also develops achievements in the basketball field. However, based on observations obtained data that a decline in achievement at this club. In a preliminary study, the dominant problem affecting was dribling errors, which caused many teams to fail to attack. The factors that are thought to influence this condition are the lack of training models and the variety of dribling training models. For this reason, research will be carried out in making the dribling training model. This study aims to: 1) develop a dribling Exercise model in UNP basketball athletes, 2) Know the effectiveness of using the dribling Exercise Model in UNP basketball athletes. The following research procedures: establish research and development research procedures consisting of the following steps: (1) explore the potential and problems, (2) data collection, (3) product design, (4) design validation, (5) and (6) product trials. The results of the research are the creation of basketball dribbling training model products. Expert validation and product trials state that the basketball dribling exercise model is feasible to use.
\end{abstract}

Keywords: Long Jump, Explosive Power

\section{INTRODUCTION}

The government's commitment to sports, especially in terms of forming sports achievements is outlined and explained in the Law on the National Sports System of the Republic of Indonesia Number: 3 Year (2005: 16). concerning the development and development of achievement sports in Article 27 Paragraph: 4 which states that: "Development and development of achievement sports is carried out by empowering sports associations, fostering and fostering national and regional sports, and organizing competitions in stages and in a sustainable manner".

Based on the above quotation explained by the government that the development of sports in Indonesia is directed at the formation and development of achievements. To achieve an achievement in a sport, the government instructed Indonesian people to establish a sports club or association. One sport that was developed for achievement in Indonesia is basketball. Government efforts to develop basketball through PERBASI (Indonesian Basketball Association).

To be able to play basketball, one must master the basic techniques of playing basketball properly individually. This is because basketball is not just a team game but also a game that requires individual skills. According to Fardi (1999: 24) "with a basic technique that is good and right then the efficiency and effectiveness of motion will be achieved which in turn will produce quality skills. In addition, basketball players can easily combine these basic techniques in situations that support the game without experiencing significant difficulties. "

According to A. Sarumpet in Supangat (2007) said that "there are a number of basic basketball techniques, namely: 1) Throwing and catching, 2) Dribbling, 3) Shooting, 4) Pivoting and processing feet, 5) Meray ". Of the five basic basketball techniques above, one of the most important elements is dribbling. Dribbling or dribbling techniques include various patterns of motion such as mastery of sensing skills and skills of receiving high stimulation. To be able to master the perfect dribbling technique, one must follow the applicable provisions. According to Soedikun (1992: 52), "dribbling is one that is allowed by regulations to dribble in all directions". A basketball player carries the ball more than one step when the ball is reflected either by walking or running.

The UNP Basketball Club is one of the clubs that also develops achievements in the basketball field. However, based on observations obtained data that a decline in achievement at this club. In the preliminary study, it was found that the dominant problem affecting was dribling errors, causing many teams to lose points. The factors that are thought to influence this condition are the lack of training models and the variety of dribling training models. For this reason, research will be carried out in 
making the dribling training model. The purpose of this study is to develop a dribling exercise model for soccer athletes, and to find out the effectiveness of using the dribling exercise model for basketball athletes. The urgency of the research is, this research will add dribling Exercise Model to UNP basketball athletes, and this research will produce various models that can improve achievement.

An ordinary model is defined as a pattern created or produced. In Robins' opinion, "A model is an abstraction of reality; a simplified representation of some real-world phenomenon (Stephen: 1996: 25), that is to say, a model is a representation of a phenomenon that exists in the real world. A model illustrates a whole concept that is interrelated and has a mindset. The model in the context of development is concluded as a development arrangement so as to achieve the desired goals. In other words the model is a set of general steps that provide guidelines for designing a program.

Designing the training model must begin with a needs assessment, because it is related to efforts to solve problems related to the learning process in learning a material or learning material (Sanjaya: 2008: 67). To be able to produce certain products used research that is needs analysis and to test the effectiveness of these products in order to function in the wider community, it is necessary to test the effectiveness of these products. So research and development are longitudinal (multy years stage) (Sugiyono, 2011: 297).

\section{METHODS}

In accordance with the type of research developed, namely research development. The steps are as follows: (1) explore the potential and problems, (2) data collection, (3) product design, (4) design validation, (6) product trials

\section{RESULT AND DISCUSSION}

A. Result

1. Exploring the potential and problems

a) The basic techniques in basketball are: 1) Throwing and catching (passing and catching), 2) Dribbling, 3) Shooting, 4) Pivoting and footwork, 5) Pawning ". Of the five basic basketball techniques above the most important element is shooting

b) The training model is a form of exercise consisting of forms of exercise.

c) Learning basic basketball skills is easy to learn and analyze when displayed in visual form.

\section{Data Collection}

Analysis of needs (through observation) in August 2019). The results of observation are:

a) The training provided is not well programmed in other words the trainer provides training based on what is remembered in the field.

b) The trainer has not used a specific training model to improve basic dribbling technical skills.

c) In the preliminary study, the dominant problem affecting was dribbling error, which caused many teams to lose points. The factors that are thought to influence this condition are the lack of training models and the variety of dribbling training models. For this reason, research will be carried out in making the dribbling training model. the training provided is not yet focused on one of the required technical elements

\section{Product design}

The results of developing a training model for basketball athletes to produce a basketball dribbling skill training model. The aim of developing a model for athletes at Padang State University is to produce an effective training model.

Preliminary study data obtained from the results of the literature study will be presented and needs analysis through field observations conducted during training and competition activities at Padang State University. Expert validation data were obtained through a questionnaire from three basketball coach experts. Trial data from expert basketball coaches were collected using a questionnaire instrument, for (1) starting field trials of 10 athletes, (2) main field trials of 50 athletes of Basketball State University of Padang ,. Basketball athletes from Padang State University used in trials were taken at random. In this study, researchers wanted to find out the impact of using products such as training projects conducted by Borg and Gall, so it was necessary to form two groups, namely the experimental group and the control group, so that a difference test with a t-test could be done.

Dribble Exercise Model

1) Dribble with 2 hands and 2 balls in place, with the same reflection (30 seconds)

2) Dribble with 2 hands and 2 balls in place, with different reflections ( 30 seconds)

3) Dribble in front of both feet with 2 hands and 1 ball (30 seconds)

4) Dribble between legs

5) Dribble Speed

6) Dribble backwards,

7) Dribble zig zag,

8) Dribble sideways, 
9) Dribble speed and reverse,

10) Dribble backwards and zig-zag,

11) Dribble sideways and speed

12) Dribble zig-zag and sideways

13) Dribble speed, backward and sideways

14) Dribble backward, zig-zag and speed,

15) Dribble sideways, speed and zigzag,

16) Dribble zig-zag, sideways and speed

\section{Expert Validation}

From the validation of three Basketball coach experts, the results were obtained $(81.18 \%)$, so that the basic technical training model playing basketball was very appropriate. input from the three basketball coach experts was found that the training formation on this dribbling skill model needs to pay attention to the number of groups to be more numerous and each player with one ball so that each participant has the same opportunity and a lot of repetition of motion.

\section{Product Testing}

The trial results obtained $(84.55 \%)$, so that this dribbling exercise model is very feasible to use. Some of the observations in this small group trial field notes are obtained as follows: (1) The width of the field area of the form of training is too small so it is difficult for athletes to do dribbling, to further widen the training area distance. After a series of trials and revisions and improvements to the draft model, the dribbling training model for Padang State University athletes was composed of 16 variations of the dribbling training model.

\section{B. Discussion}

Based on the results of the trials that have been explained, it is known that the product model of dribbling training playing basketball developed in this study is considered to meet the requirements and is effective to be socialized and applied in basketball practice in Padang State University. This product development model for dribbling training playing basketball presents training material that features important elements in running a training program and basic material in basketball training. This is presented in a systematic form starting from the easy stages, increasing to a more difficult level and containing an element of excitement and ending with the actual form of the game.

\section{CONCLUSION}

The basketball dribbling training model that has been created produces the final product in the form of a guidebook and a video model of basketball dribbling training. With this book and video, it will be useful for trainers as a guide and guide in carrying out the training process to improve performance effectiveness.

\section{REFERENCES}

[1] Fardi, Adnan. 1999. Bola Basket Dasar. Padang :FIK UNP.

[2] Sarumpaet, Jhonson A. 1986. Dasar-Dasar Pembinaan Gulat. Padang: FPOK IKIP Padang.

[3] Supangat, Awal. 2007. Hubungan Antara Daya Ledak Otot Tungkai, Kelentukan Pergelangan Tangan dan Tinggi Badan Terhadap Hasil Tembakan Lay Up Kanan Dalam Permainan Bola Basket. Semarang: Skripsi Universitas Negeri Semarang.

[4] Dinata, Marta. 2008. Bola Basket konsep dan Teknik Bermain Bola Basket.Jakarta:Penerbit Cerdas Jaya.

[5] Sodikoen, Imam. 1992. Olahraga Pilihan Bolabasket. Padang : FPOK IKIP Padang.

[6] Sodikun, Imam. 1992. Olahraga Pilihan Bola Basket. Jakarta: Departemen Pendidikan dan Kebudayaan.

[7] Witarsyah. 2005. Bola Basket Pendalaman. Padang : FIK UNP.

[8] Tomoliyus. 2001. Pendekatan Keterampilan Taktis dalam Pembelajaran Bola Basket. (konsep dan metode). Jakarta : Depdiknas Dirjen Pendidikan Dasar dan Menengah dan Dirjen Olahraga.

[9] Madri. 2012. The Basic Learning Basketball Technique. Padang : Sukabina Press.

[10] Wissel, Hall.1997. Bola Basket Program Pemahiran Teknik dan Taktik. Jakarta: Rajagrafindo.

[11] Kosasih, E. 1993. Olahraga Teknik dan Program Latihan Jakarta: Akademik Presindo.

[12] Kosasih Danny. 2008.Fundamental Basketball, First Step To Win. Semarang: ElwasOffset Yayasan Pendidikan Nasional Karangturi.

[13]Fox, EL Bower RW. 1993. Sports physiology. 3 rd edition. New York: Wm C Brown Publishers.

[14] Departemen Pendidikan dan Kebudayaan, Direktorat Jendral Olahraga dan Pemuda. 1992. Coaching Bolabasket. Jakarta : Proyek Pendidikan Olahraga STO/SMOA.

[15] Hadeli .2002. Metode Penelitian Kependidikan. Padang : Baitul Hikmah Pers

[16] Muchtar, Remmy. 1992. Olahraga Pilihan Bolabasket. Depdikbud. Proyek Pembinaan Tenaga Kependidikan.

[17] PB. PERBASI . 1999. Pengaturan Permainan Bola Basket. Jakarta : PERBASI.

[18]PERBASI. 2001. Peraturan Permainan Bola Basket. Jakarta: Pengurus Besar Persatuan Bolabasket Seluruh Indonesia. 
[19] Sajoto,M. 1988.Pembinaan Kondisi Fisik Semarang:IKIP Semarang.

[20] Sugiyono. 2009. Metode Penelitian Pendidikan Pendekatan Kuantitatif, Kualitatif, dan R\&D. Bandung: Alvabeta.
[21] Suharno, HP. 1993. Metodologi Pelatihan. Jakarta : Komite Olahraga Nasional Pusat.

[22] Syafruddin, 2011. Ilmu Kepelatihan Olahraga Teori Dan Aplikasinya Dalam Pemnbinaan Olahraga. Padang: FIK UNP. 